\title{
High Energy-Efficient District Cooling System and Its Engineering Applications in India
}

\author{
Chen, Zhuolun; Riahi, Lily; Hickman, Benjamin
}

\section{Published in:}

Proceedings of the 11th International Symposium on Heating, Ventilation and Air Conditioning

Link to article, DOI:

10.1007/978-981-13-9528-4_143

Publication date:

2020

Document Version

Peer reviewed version

Link back to DTU Orbit

\section{Citation (APA):}

Chen, Z., Riahi, L., \& Hickman, B. (2020). High Energy-Efficient District Cooling System and Its Engineering Applications in India. In Proceedings of the 11th International Symposium on Heating, Ventilation and Air Conditioning (pp. 1419-1428). Springer. Environmental Science and Engineering https://doi.org/10.1007/978981-13-9528-4_143

\section{General rights}

Copyright and moral rights for the publications made accessible in the public portal are retained by the authors and/or other copyright owners and it is a condition of accessing publications that users recognise and abide by the legal requirements associated with these rights.

- Users may download and print one copy of any publication from the public portal for the purpose of private study or research.

- You may not further distribute the material or use it for any profit-making activity or commercial gain

- You may freely distribute the URL identifying the publication in the public portal 


\title{
High Energy Efficient District Cooling System and Its Engineering Applications in India
}

\author{
Zhuolun Chen ${ }^{1,2,3(\bowtie)}$, Lily Riahi ${ }^{3}$ and Benjamin Hickman ${ }^{3}$ \\ ${ }^{1}$ Architecture Design and Research Institute, School of Architecture, \\ South China University of Technology, Guangzhou, China 510640 \\ ${ }^{2}$ Copenhagen Centre on Energy Efficiency, UNEP-DTU Partnership, \\ Copenhagen, Denmark 2100 \\ ${ }^{3}$ District Energy in Cities Initiative, Cities Unit, Economy Division, \\ UN Environment Program, Paris, France 75015 \\ zhchen@dtu.dk, arzlchen@scut.edu.cn, https://orcid.org/0000-0001- \\ $5348-1117$

\begin{abstract}
This paper introduces the studies and experience learned in district cooling project development in developed countries and adaptation process in India for city-level rapid assessment. There are 5 pilot Indian cities chosen to go through all the process of rapid assessment so as to outline the barriers, challenges and potential to develop high energy efficient district cooling system. The paper also instructs the tech-eco analysis tools for rapid assessment, which is developed by the UNEP District Energy in Cities Initiative and adapted in India. According to the results, the economic and technical boundaries of implementing district cooling systems are outlined.
\end{abstract}

Keywords: District Energy System, Tech-eco Analysis, Energy Efficiency Indicators, Climate Change.

\section{$1 \quad$ Introduction}

\subsection{UN Environment District Energy in Cites Initiative}

The District Energy in Cities Initiative, which is one of the six accelerators under United Nations' (UN's) Sustainable Energy for All (SEforAll) platform, is a multi-stakeholder partnership coordinated by UN Environment (UNEP). The Initiative, together with over 46 organizations and 45 champion cities on board as its partners, is supporting national governments and municipalities to accelerate investment in modern district energy systems (DES) through implementing incentive policies, programs and project pipelines on district energy. It is engaging the efforts to transform market in the sectors of traditional heating and cooling to solutions with higher energy efficiency and more renewable energy. 
According to studies finished by UNEP [1], it is reported that one of the least-cost and most energy efficient solutions in reducing emissions and primary energy demand is to develop climate resilient and low-carbon DES in cities. However, there is no fixed term used worldwide for 'district energy systems'. UN Environment's report 'District Energy in Cities: Unlocking the Potential of Energy Efficiency and Renewable Energy' explains the technology options in detail, as well as the benefits, policies (national and local) and business models, as shown in Fig. 1.

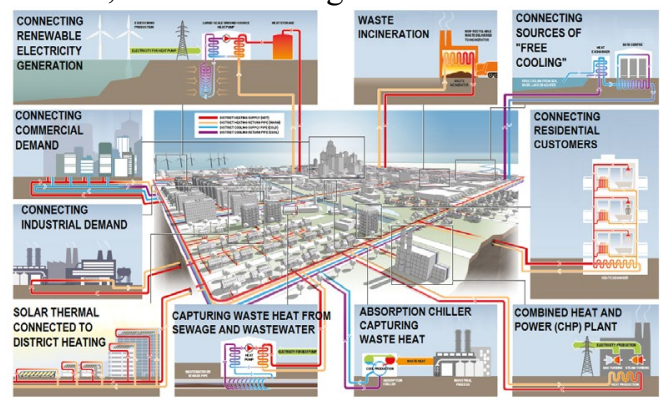

Fig. 1. Definition of district energy system and its components

District cooling (DC) systems are a smart city solution that delivers the comfort of air conditioning with significantly reduced impacts, in particular, considerably reduced electricity consumption for space cooling. A district cooling system is a neighborhoodscale air conditioning system that produces chilled water in a central plant and distributes it to multiple buildings via underground insulated pipes, replacing buildings' standalone air conditioning systems. Centralizing production of chilled water and connecting diverse consumers means the central plant can be operated using lots of different efficient sources, and have large-scale thermal storage, leading to more efficient, reliable and environmentally friendly cooling in buildings. By cooling several buildings in a city neighborhood, DC provides the economies of scale required to integrate large scale renewables or waste heat that cannot be connected at the individual building scale, lowering electricity consumption by up to $50 \%$. Meanwhile, the district cooling systems dramatically reduce cooling electricity consumption and shift electricity demand away from peak periods.

\subsection{Pilot Indian cities for rapid assessment}

Today, $30 \%$ of Indians live in cities and it is estimated that by 2050 , this figure will reach 50\%[2]. Cities are the powerhouses of India's economy and will contribute nearly $70 \%$ of the country's GDP by 2030 [3]. Rapid urbanization and rising income levels means the real-estate market is one of the largest in the world and responsible for $8 \%$ of India's GDP, growing to a potential $17 \%$ by $2025 \%$ [4]. Cities consume $80 \%$ of India's electricity demand [5] and an increasingly significant contributor, albeit well hidden, is electricity demand for space cooling.

As part of the UN Environment's Global Environment Facility (GEF-6) funded project, 5 pilot cities in the pilot country of India are selected to be rapidly assessed for their DC potential. Until the rapid assessment finished at the end of 2017, there is no 
DC systems on operation in these 5 cities. These assessments also examine space cooling's current impacts, ongoing and planned city programs through which DC could be promoted and the policy options available to each city. In-depth stakeholder consultations were undertaken in each city and potential sites identified, high-level techno-economic assessments established, cooling demands estimated, policy and regulatory frameworks analyzed and recommendations to city, state and national governments developed. When selecting the five cities, the main consideration includes geographical diversity, demographics climatic conditions and real estate development levels.

All of the pilot cities are part of the Government of India's Smart City Mission and Solar Cities Program [4]. These cities, namely Bhopal, Coimbatore, Pune, Rajkot and Thane, are located in different areas with various climate conditions. Electricity consumption in all these cities is distinctly seasonal and in direct correlation with humidity and/or temperature. This seasonality is expected to be predominantly caused by space cooling and will only grow as demand for air conditioning increases, increasing the difference between peak and off-peak electricity demand. Furthermore, it is known that large offices, retail and some hospitals will be using air conditioning year-round. Table 1 shows the difference between the highest and lowest monthly consumptions in each city. The peak of electricity consumption is actually in July as this month has the highest average relative humidity at $90 \%$ (rather than May which experiences highest average temperature).

Table 1. Difference between highest and lowest monthly electricity consumption

\begin{tabular}{cccc}
\hline City & $\begin{array}{c}\text { Highest monthly electricity } \\
\text { consumption }(\mathrm{GWh})\end{array}$ & $\begin{array}{c}\text { Lowest monthly electricity } \\
\text { consumption }(\mathrm{GWh})\end{array}$ & $\begin{array}{c}\text { Percentage increase } \\
\text { from baseload }\end{array}$ \\
\hline Bhopal & 147.92 & 95.39 & $55 \%$ \\
Coimbatore & 204.01 & 184.13 & $11 \%$ \\
Pune & 457.02 & 366.90 & $25 \%$ \\
Rajkot & 143.97 & 101.94 & $41 \%$ \\
Thane & 256.60 & 180.21 & $42 \%$ \\
\hline
\end{tabular}

\section{Methodologies}

\subsection{Work path for implementation of district energy system from national government to project level}

In order to assist the cities to implement district cooling projects, it is required not only to provide technical support, but also incentive policy framework, business models and financial support mechanism design etc.. The Initiative has developed different work paths to support countries and cities with different development conditions of district energy. For those without any district energy systems before, the work path of 'Topdown' is applied to unlock the market from national government or ministries, to citylevel municipalities and finally to demonstration projects. It aims to engage stakeholders from private and public sectors in different levels and showcase the technical feasibility, economic viability and environmental benefits through pilot projects from steps 
of national level incentive policies or standards to municipality level of urban planning regulation and demonstration. For those with district energy systems before but for some reasons they are not energy efficient or environmentally friendly, the work path of 'Bottom-up' is applied to retrofit or upgrade the existing projects to achieve certain energy efficiency levels, and from there standards, regulations, business models etc. are developed to support the duplication of best practice. Thus, the whole framework is developed from practical projects (bottom) to regional and national policies (top). The work paths of both 'Top-down' and 'Bottom-up' are shown in Fig. 2. No matter what kind of work path is applied, the deliverables of the Initiative are similar.

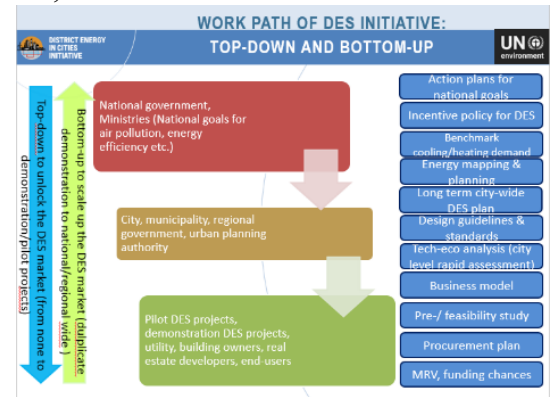

Fig. 2. Work path of District Energy in Cities Initiative

\subsection{Tech-eco analysis tools for rapid assessment}

In order to support the fast decision making process in early stage of project development, it is necessary to carry out a rapid assessment to find out the regions with higher potential technically and cost-effectively for district cooling systems than others. During the rapid assessment, it is required to transfer the data and information from energy mapping and urban planning to calculate basic system parameters to determine the size, investment, demand and operation cost, as well as give out parametric analyze on sensible factors to evaluate the feasibility of the system.

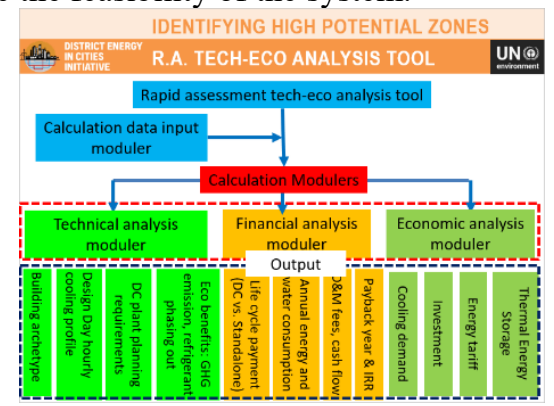

Fig. 3. Tech-eco analysis tool for rapid assessment

A tool to assist all these analysis is developed and adapted to Indian conditions, as the framework shown in Fig. 3. It takes data input from urban planning to three calculation modular and gives out results of requirements for district cooling project devel- 
opment. As a result, the decision makers in the municipalities can easily have the impression of environmental benefits of the district cooling system as well as the total investment, size, land, energy consumption and payback period. The tool can fast evaluate the impact of different key factors to the overall economic viability and give out sensitive analysis results.

\section{Results and discussion}

\subsection{Benchmarking cooling demand of archetype buildings}

The relatively high average temperatures and humidity of the 5 pilot Indian cities indicate that in all cities there is a suitable climate to support district cooling systems. However, space cooling is dependent on more than climate. Building efficiency, building occupancy and affordability are all significant drivers of air conditioning and make calculating cooling demands for generic building archetypes very difficult. Building occupancy and interior heat gain have a higher impact on cooling demand, especially for commercial buildings, than climate. Based on the Building Energy Conservation Code, hourly cooling load of different archetype buildings on the design day are calculated and annual cooling consumption are simulated, as shown in Fig. 4. The work of benchmarking these cooling load and annual consumption with real on-site measured data is ongoing in the city of Thane.

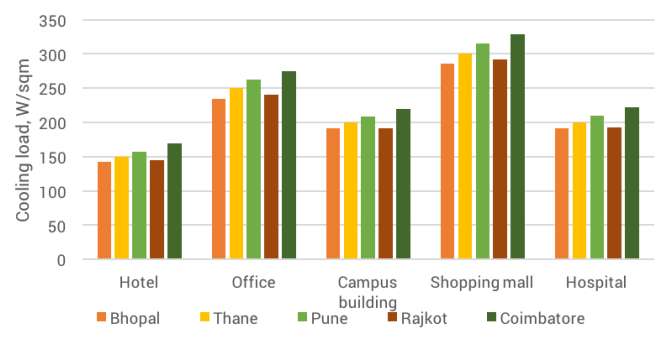

Fig. 4. Calculated results of Cooling load for 5 pilot cities

\subsection{Tech-eco analysis results on potential district cooling projects}

Overall economic analysis results. Fig. 5 and 6 show the findings for a typical mixeduse development across the cities served by an electricity-based district cooling system. The prices paid for cooling vary by cities primarily due to the varying electricity prices. With such returns on investment, from a fast comparison of one development archetype, it can be seen that given favorable financing support district cooling projects would be profitable to investors, beneficial to the environment and lower-cost to the consumers. For the consumer side, connecting to district cooling can bring them at least $20 \%$ saving annually for the whole life cycle while cutting down almost $80 \%$ of the initial investment on the first year, when comparing to standalone systems. 


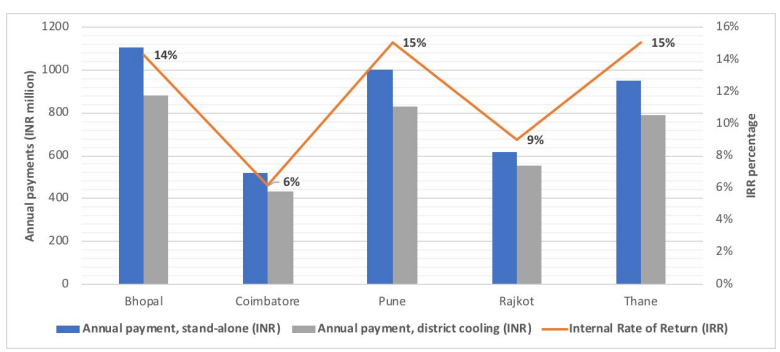

Fig. 5. Eco analysis results of IRR and annual payment

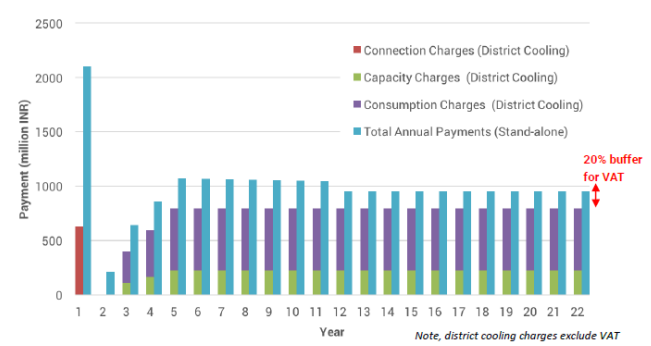

Fig. 6. Cost comparison for the consumers (DC vs. stand-alone)

Project level rapid assessment results: an example in Thane. Through the rapid assessment, regions or township development with high potential for district cooling are highlighted in each of the pilot cities. Under the help of the tool, hourly cooling profile, cost-effectiveness and environmental benefits of district cooling development are analyzed, as shown in Fig. 7 to 9. These are the results of Thane greenfield project, but the same analysis are carried out for all the potential projects in all the 5 pilot cities.

The characteristics of DC plant (built-up area, outdoor space for cooling towers and land requirements), investment, annual cooling supply, electricity and water consumption are calculated. Sensitive analysis on thermal energy storage (TES) and its cost effectiveness are taken into account to find out what percentage of storage is suitable to current tariff. The results for different coverage ratios of ice TES for peak load periods, ranging from $0 \%$ to $30 \%$ show that the application of TES results in higher chilled water price under a fixed IRR. The reason is that the electricity price between off-peak and peak periods cannot cover the increased cost of TES. In order to make the TES system cost-effective so that the whole electrical grid can benefit from the peak load shifting, it is suggested to establish a special subsidy on electricity price of off-peak period for TES.

The economic analysis results of different subsidy percentage under different ratio of ice show that all cases have the similar IRR of $17 \%$. According to the results, at least $20 \%$ of subsidy on off-peak electricity price is required to make TES cost-effective as at this point the chilled water price is below the chilled water price for a system without TES (0.233 USD/TR.h).

Electricity savings of $7.53 \mathrm{GWh}$ of electricity annually (33\% reduction from standalone) are expected and a reduction in peak power demand of $9.2 \mathrm{MW}(36 \%$ reduction 
from stand-alone). The district cooling system can also contribute to refrigerant phasing out, due to reduced cooling capacity in the whole district. Over the life time, this is expected to be 4.4 tons, as compared to water-cooled chillers.

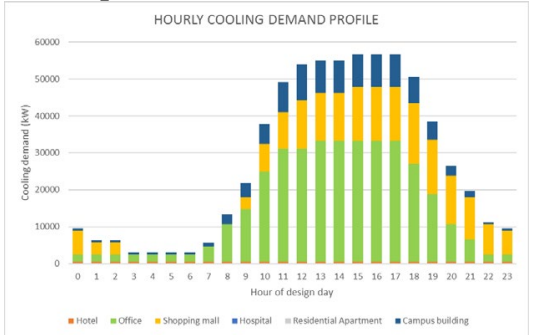

Fig. 7. Hourly cooling profile of all the buildings in the region

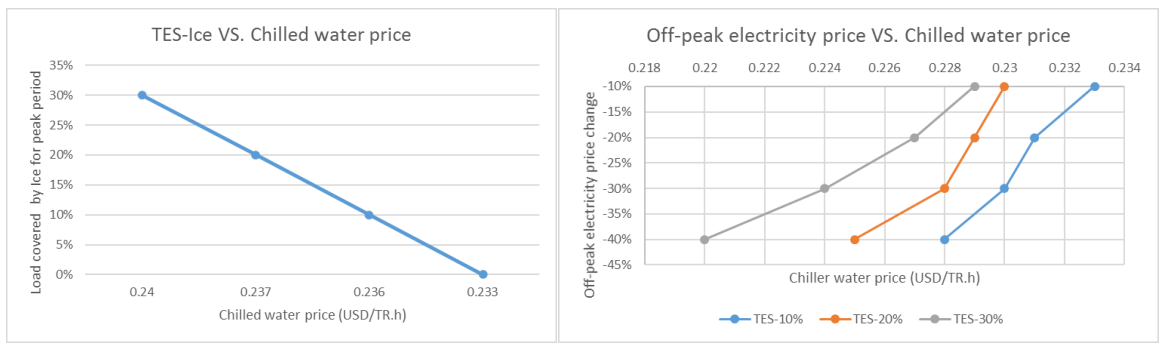

Fig. 8. Cost-effectiveness sensitive analysis of thermal energy storage (TES)

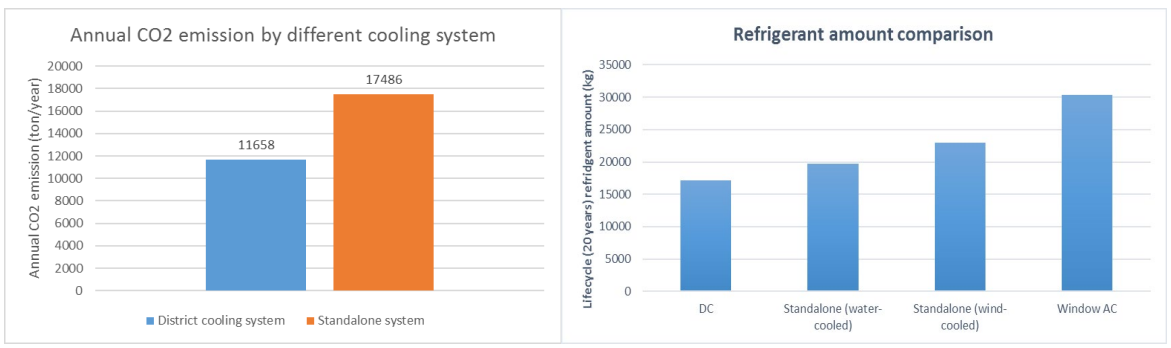

Fig. 9. Environmental benefits of DC in Thane greenfield project

\section{$4 \quad$ Recommendations and conclusions}

\subsection{Integration with Smart City Mission}

All cities have been shortlisted amongst 100 cities to be developed as Smart Cities under the Government of India's Smart Cities Mission. Under the smart city proposals, cities are setting out their priorities and commitments to deliver smarter, more sustainable and liveable cities. The smart city proposals are holistic in nature and include various smart solutions addressing water, solid waste, sewage, energy, smart grid. 
District cooling can help cities to integrate the priority sectors presented within their smart city proposals, improving environmental credentials and lowering costs. For example, district cooling systems can make use of surplus heat from waste-to-energy projects, help balance local electricity networks with cold storage and use Treated Sewage Effluent (TSE) as cooling water (as is done in the U.A.E). Many cities have established Special Purpose Vehicles (SPVs) to design and implement Smart City plans.

\subsection{City-level urban energy mapping and planning}

Municipal corporations can effectively catalyze district cooling deployment first and foremost in their role as planners and regulators. In general, the cities assessed have sufficient authority over building permissions, land-use planning, zoning and building regulations to successfully promote district cooling. Many of the cities do have a larger metropolitan-level authority they work with to develop long-term development plans and promote high-growth, as such strong coordination will be necessary for policy development. All the cities have long-term Development Plans that detail land utilization and are used to regulate and guide development, often over a period of 20 years. The Plan also broadly prescribes the planning norms and development controls that will apply in the city.

Acknowledgments. Both the study in this paper and implementations are supported by the Global Environment Facility (GEF-6) funding project "Increasing Investments in District Energy Systems in Cities - a SE4All Energy Efficiency Accelerator". The methodologies used in technical-economic analysis are results from academic research projects of National Scientific Fund(No. 51108185 and No. 51778235), Province natural science fund of Guangdong(No. 2016A030313513), and the State Key Laboratory of Subtropical Building Science(NO. 2019ZA04 and No. 2013KB24).

\section{References}

1. UN Environment. District Energy in Cities: Unlocking the Potential for Energy Efficiency and Renewable Energy. (2015)

2. Government of India. Population Projections for India and States 2001-2026. (1999)

3. Mckinsey Global Institute. India's urban awakening: Building inclusive cities, sustaining economic growth. (2010)

4. Government of India. Planning Commission. (2015)

5. UN-Habitat. Sustainable Urban Energy: A Sourcebook for Asia. (2012)

6. Abhyankar et al. Accelerating Improvements in the Energy Efficiency of Room Air Conditioners (RACs) in India: Potential, Cost-Benefit, and Policies (Interim Assessment). Lawrence Berkeley National Laboratory. (2016) 